\title{
NEW DISTRIBUTIONAL RECORDS OF THE RED SQUIRREL (TAMIASCIURUS HUDSONICUS) IN WESTERN NEW MEXICO AND EVIDENCE FOR ITS EXTIRPATION FROM THE ZUNI MOUNTAINS
}

\author{
Jennifer K. Frey ${ }^{1,2,3}$
}

\begin{abstract}
In the American Southwest, the red squirrel (Tamiasciurus hudsonicus) occurs as disjunct populations in coniferous forests on mountaintops. There is a paucity of information concerning the species' distribution and habitat in western New Mexico. I report new records that document and verify the occurrence of red squirrels in additional montane areas in west central New Mexico, including the Mangas Mountains, Canovas Rim, Turner Mountain, Tularosa Mountains, Elk Mountains, Bearwallow Mountain, and Pinos Altos Mountains. I also report observations of red squirrels from an atypical habitat-low-elevation riparian forests. These new records suggest that the geographic distribution of the species in west central New Mexico is broader than indicated by existing records. However, I also document the apparent extirpation of red squirrels from the Zuni Mountains in northwestern New Mexico. The red squirrel is one of several avian and mammalian species associated with mixed coniferous forests that have become extirpated in this mountain range.
\end{abstract}

Key words: Tamiasciurus hudsonicus, red squirrel, distribution, extirpation, habitat, New Mexico, Zuni Mountains.

The red squirrel (Tamiasciurus hudsonicus) is broadly distributed in coniferous forests throughout northern North America and southward in the Appalachian and Rocky mountains (Hall 1981). The species reaches its southern distributional limits in the American Southwest, where it is discontinuously distributed on highelevation mountaintops (Frey 2004). In the Southwest, this squirrel is primarily associated with upper montane coniferous forest, which is typically dominated by Douglas-fir (Pseudotsuga menziesii), white fir (Abies concolor), or blue spruce (Picea pungens), and the higherelevation subalpine coniferous forest, which is dominated by Engelmann spruce (Picea engelmannii) or subalpine fir (Abies lasiocarpa; e.g., Bailey 1931, Findley et al.1975, Hoffmeister 1986, Dick-Peddie 1993). When in proximity to mixed coniferous forest, red squirrels also might rarely occur in lower montane coniferous forest, which is dominated by ponderosa pine (Pinus ponderosa; Bailey 1931, Findley et al. 1975, Dick-Peddie 1993). Bailey (1931), Findley (1961), and Findley et al. (1975) compiled specimen records of red squirrels in New Mexico, including records from Mount Taylor and the Zuni Mountains in northwestern New Mexico, and the San Mateo, Mogollon, and Black Range mountains in west central New Mexico. In addition, Bailey (1931:76) reported observations from the San Francisco and Elk mountains in west central New Mexico, while his reports from "Escadillo Mountain" likely referred to Escudilla Mountain in adjacent Arizona. However, knowledge about site-specific habitats of T. hudsonicus and its geographic distribution in New Mexico is incomplete. Thus, the purpose of this research was to (1) report new records from 7 montane areas in west central New Mexico, (2) report observations in a low elevation, nonconiferous forest habitat, (3) provide information on habitat at new locations, and (4) clarify the species' status in the Zuni Mountains.

Montane Records.-The Mogollon Plateau is an extensive region of high-elevation and continuous montane coniferous forest extending across central Arizona into Catron County, New Mexico. Three localities represent the first records of red squirrels on the Mogollon Plateau north of the San Francisco River and Plains of San Agustin (Mangas Mountains, Canovas Rim, and Turner Peak). I collected 4 red squirrels from the Mangas Mountains, Catron County, 6-9 August 1994 (Fig. 1, Appendix 1). The Mangas Mountains are a relatively low

\footnotetext{
${ }^{1}$ Museum of Southwestern Biology and Department of Biology, University of New Mexico, Albuquerque, NM 87131.

${ }^{2}$ Present address: Department of Fish, Wildlife, and Conservation Ecology and Department of Biology, New Mexico State University, Box 30003, Campus Box 4901, Las Cruces, NM 88003-0003. E-mail: jfrey@nmsu.edu

3Present address: Frey Biological Research, Box 294, Radium Springs, NM 88054. E-mail: frey_b_r@fastwave.biz
} 


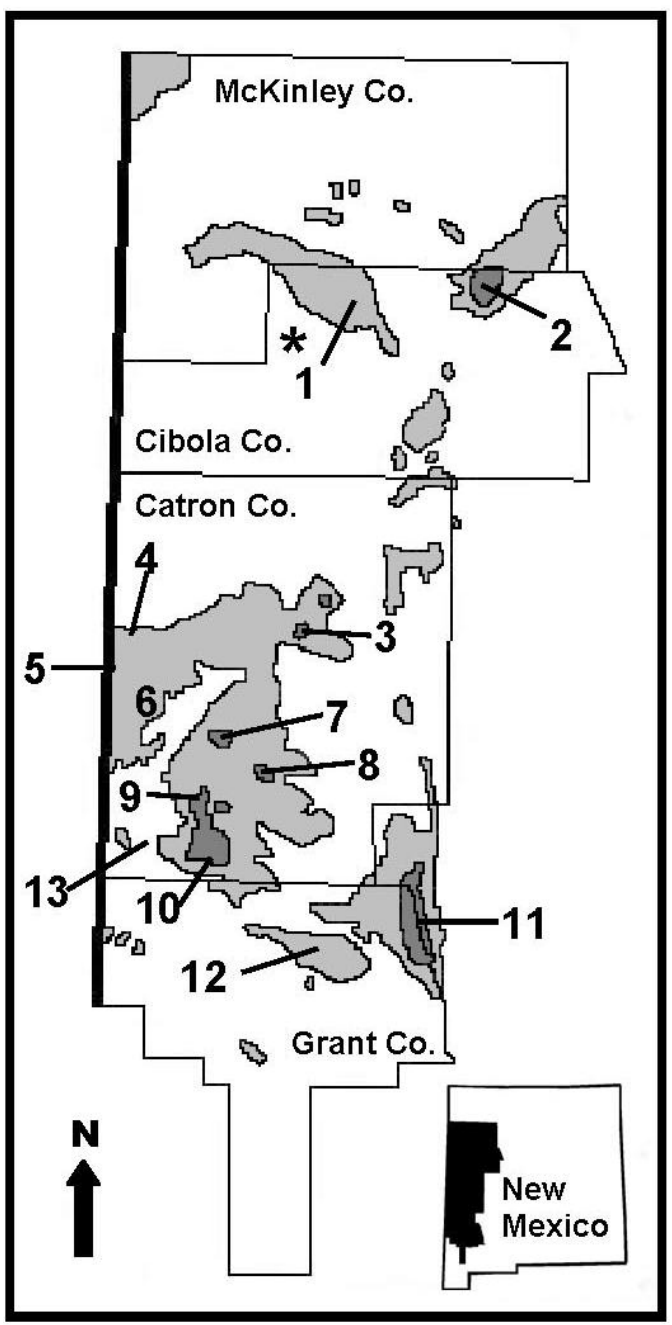

Fig. 1. Distribution of the red squirrel (Tamiasciurus hudsonicus) in west central New Mexico. Light-gray shading represents lower and upper montane coniferous forest, and dark-gray shading represents subalpine coniferous forest. Numbers refer to records based on the present study and studies by Bailey (1931) and Findley et al. (1975): (1) Zuni Mountains, (2) Mount Taylor, (3) Mangus Mountains, (4) Canovas Rim, (5) Turner Peak, (6) San Francisco Mountains, (7) Tularosa Mountains, (8) Elk Mountains, (9) Bearwallow Mountain, (10) Mogollon Mountains, (11) Black Range, (12) Pinos Altos Mountains, and (13) Glenwood and Pleasanton. The asterisk represents El Morro. Locations of forest types are based on information from Dick-Peddie (1993).

(maximum elevation $=2954 \mathrm{~m})$ range at the northern end of the Mogollon Plateau, and the range has one of the smallest areas of mapped subalpine coniferous forest of any range in New Mexico (Brown and Lowe 1980, Dick-Peddie
1993). This range also is relatively isolated from other high peaks on the Mogollon Plateau. Specimens were collected in Chavez Canyon (elevation ca. $2700 \mathrm{~m}$ ) on the northeast side of Mangas Mountain. Habitat was mixed coniferous forest dominated by quaking aspen (Populus tremuloides), ponderosa pine, Douglas-fir, southwestern white pine (Pinus strobiformis), and white fir. Common juniper (Juniperus communis) was a dominant shrub. Cutting of trees had thinned the forest and resulted in an abundance of debris on the ground.

On 15-16 September 1994, I collected 7 red squirrels on the Canovas Rim, Catron County. Canovas Rim is ca. $5 \mathrm{~km}$ wide and extends for ca. $13 \mathrm{~km}$ in an east-west orientation from Jones Peak in the east to Coyote Creek (Apache Co., AZ) in the west, and to Jenkins Creek in the south. Elevation on top of the rim averages ca. $2713 \mathrm{~m}$ but reaches elevations above $2835 \mathrm{~m}$. Habitat on the rim is primarily ponderosa pine forest, but mixed coniferous forest occurs on the highest elevations, on north-facing slopes, and in canyons. I observed red squirrels in isolated patches of mixed coniferous forest but not in the surrounding savannah of ponderosa pines. For example, I collected 4 specimens from a north-facing slope dominated by Douglas-fir, southwestern white pine, white fir, aspen, and ponderosa pine. At this site, middens consisted almost exclusively of cones of white fir. Similarly, near Jenkins Creek I obtained 2 specimens from an isolated patch of riparian mixed coniferous forest dominated by blue spruce.

I obtained one red squirrel on 16 September 1994 from Turner Peak, Catron Co. This is a small mountain (area above $2682 \mathrm{~m}$ is ca. 1.7 $\times 0.8 \mathrm{~km}$; maximum elevation $2882 \mathrm{~m}$ ) on the New Mexico-Arizona border supporting mixed conifer forest within a region that is otherwise a ponderosa pine forest. It is located ca. $5 \mathrm{~km}$ west of Escudilla Mountain, Apache Co., Arizona, where red squirrels were previously reported (Bailey 1931, Hoffmeister 1986).

Specimens of red squirrels also are available from 3 new montane areas on the Mogollon Plateau south of the San Francisco River and Plains of San Agustin (Tularosa Mountains, Elk Mountains, and Bearwallow Mountain). On 1-2 August 1994, I collected 6 red squirrels from the summit of Eagle Peak (elevation ca. $2800 \mathrm{~m}$ ) in the Tularosa Mountains, Catron Co. These specimens represent the first documentation 
of the red squirrel in this mountain range. Dominant trees were Douglas-fir and quaking aspen with an understory dominated by currants (Ribes spp.). Other species present included white fir, Engelmann spruce, subalpine fir, and elderberry (Sambucus sp.). Ponderosa pine was common on an adjacent dry, southfacing slope. Based on the number of visual observations and the frequency of vocalizations heard, red squirrels appeared to be abundant on this peak during summer 1994. This was in marked contrast to the summer of 1997, when I visited this locality but observed no red squirrels or fresh sign of them.

Bailey (1931) reported that red squirrels were common in the Elk Mountains, but neither he nor Findley et al. (1975) reported specimens. On 4 September 1994, I collected 2 red squirrels from these mountains in a shallow canyon on the lower slopes (elevation ca. $2560 \mathrm{~m}$ ) of the southwest side of Elk Mountain, Catron Co. Although the area was dominated by ponderosa pine, red squirrels were only discovered in a small patch of mixed coniferous forest dominated by Douglas-fir, where a northfacing canyon wall became high and steep.

On 5 September 1994, I collected 3 red squirrels from the peak (elevation ca. $3030 \mathrm{~m}$ ) of Bearwallow Mountain, Catron Co., in Engelmann spruce-subalpine fir forest. Bearwallow Mountain and adjacent Corner Mountain are often regarded as a part of the Mogollon Mountains but are separated from the main massif of the Mogollon Mountains by the drainages of Mineral and Willow creeks. Red squirrels were previously reported from the main massif of the Mogollon Complex (Findley et al. 1975).

Five specimens were discovered in the Western New Mexico University Gila Center for Natural History. They were collected from the Pinos Altos Mountains, in Grant County and represent the first records of the red squirrel south of Mogollon Plateau and south of the drainages of the Gila and Mimbres rivers. The Pinos Altos Mountains reach a maximum elevation of $2751 \mathrm{~m}$, and the area is mapped as montane coniferous forest (Brown and Lowe 1980, Dick-Peddie 1993). This area of mapped montane coniferous forest is isolated from montane coniferous forest on the Mogollon Mountains and Black Range by intervening pinyon-juniper (Pinus-Juniperus) woodland (Fig. 1; Brown and Lowe 1980, Dick-Peddie 1993). The specimens included one obtained on 23
September 1961 from the north slope of Signal Peak and one obtained on 24 September 1966 from Signal Peak. Signal Peak is one of the highest peaks in the range (ca. $2740 \mathrm{~m}$ elevation). Three additional specimens were obtained 2 October 1982 from the vicinity of an aspen grove within a Douglas-fir forest at ca. $2316 \mathrm{~m}$ elevation on the north-facing slope.

The 7 new montane records from the Mogollon Plateau undoubtedly represent previously undocumented occurrences rather than recent range extensions. The poor documentation of red squirrel distribution is somewhat surprising given that this species is generally conspicuous in mammalian faunas due to its diurnal behavior, distinctive vocalizations, and construction of prominent and distinctive middens. However, there has been little research on mammals of the Mogollon Plateau in New Mexico (Frey et al. 2008). I expect that the species' distribution in this region is even broader than the records presented herein. Based on documentation of T. hudsonicus in relatively small patches of mixed coniferous forest, it seems likely that the species is capable of occurring anywhere on the Mogollon Plateau where mixed-coniferous habitats exist.

LOW-ELEVATION RECORDS.-Observations of red squirrels at low elevations are available from the vicinity of Pleasanton, Catron County, at the western base of the Mogollon Mountains. Around 1970 a red squirrel wintered at a residence within meters of the San Francisco River (J.P. Hubbard personal communication). Elevation was ca. $1400 \mathrm{~m}$, and the habitat was dominated by lowland riparian trees, including Fremont cottonwood (Populus fremontii), Godding willow (Salix gooddingii), Arizona walnut (Juglans major), and Arizona sycamore (Platanus wrightii). The red squirrel appeared to dominate the larger Arizona gray squirrel (Sciurus arizonensis), including at birdfeeders and in walnut trees, in which the latter preferentially foraged. Around 1980 a red squirrel was observed in winter along Whitewater Creek near the Glenwood Fish Hatchery in Glenwood, Catron County (J.P. Hubbard in litt.). Elevation was ca. $1350 \mathrm{~m}$, and the habitat was pecan trees (Carya illinoiensis; J.P. Hubbard personal communication). These records likely were the result of dispersal of individuals from mixed coniferous forests in the mountains, probably along riparian corridors such as Whitewater Creek. Movements through ponderosa pine or 
nonconiferous forests likely are important in colonizing and maintaining persistence of the species in small isolated patches of mixed coniferous forest.

Zuni Mountains.-Coues and Yarrow (1875:117) reported a fluid-preserved specimen of red squirrel bearing the field number $76 a$ from "El Moro [sic], N. Mex." The specimen was collected in July 1873 by H.W. Henshaw. Henshaw was an ornithologist with the Wheeler Expeditions, and his specimens were sent to the U.S. National Museum (USNM), the U.S. Army Medical Museum (presently the National Museum of Health and Medicine), and possibly the London Natural History Museum (Coues and Yarrow 1875, Bailey 1928). His specimen of T. hudsonicus could not be located in those collections (L. Barbian, P. Jenkins, R. Fisher, and S. Peurach, personal communication). Henshaw joined the Wheeler party at Fort Wingate (McKinley Co., AZ) on 12 July 1873. He departed Fort Wingate on 19 July, arriving in Fort Apache (Navajo Co., AZ) on 2 August, ahead of the main Wheeler party that traveled to Fort Apache during 5-10 August (Webb and Axtell 1986). Based on bird specimens in the USNM, Henshaw was in the vicinity of El Morro from at least 23 July to 29 July 1873. Henshaw's side trip to El Morro, which was ca. $34 \mathrm{~km}$ east-southeast of the junction of the Nutria and Zuni rivers on the main Wheeler expedition route, explains the different dates and durations of travel reported for the Fort Wingate-Fort Apache leg of the expedition (Webb and Axtell 1986). Thus, while Henshaw was at El Morro in July 1973, the specimen of red squirrel most likely was collected in the nearby Zuni Mountains.

El Morro, also known as Inscription Rock, is a butte located ca. $16 \mathrm{~km}$ southeast of Ramah, Cibola County, on the northwestern edge of the Obe Worthern Mesa Complex and near the southwestern edge of the Zuni Mountains (Bailey 1928, Julyan 1998). Historically, El Morro was a well-known and important stop for travelers (Julyan 1998). Maximum elevation on the El Morro butte is $2260 \mathrm{~m}$, although elsewhere on the mesa, elevations reach $2374 \mathrm{~m}$. El Morro supports a piñon-juniper woodland and scattered small stands of ponderosa pine, while vegetation surrounding the mesa is grassland (Dick-Peddie 1993). El Morro does not have mixed coniferous forest or even enough ponderosa pines to support species typical of lower montane coniferous forest (e.g., Abert's squirrel [Sciurus aberti], Steller's Jay [Cyanocitta stelleri], Grace’s Warbler [Dendroica graciae]; D.A. McCallum personal communication). Thus, El Morro does not provide adequate habitat to support a population of red squirrels.

Bailey (1931:76) ascribed Henshaw's specimen to the Zuni Mountains but noted that none had been taken there since. Findley et al. (1975:141) subsequently mapped the record in the Zuni Mountains (within the borders of Valencia [presently Cibola] Co.) and cited it as "El Morro, Zuni Mts. (V. Bailey 1932:76)." The Zuni Mountains are a large (ca. $25 \times 80 \mathrm{~km}$ ) range that reaches $2821 \mathrm{~m}$ elevation and is located ca. $8 \mathrm{~km}$ northeast of El Morro. DickPeddie (1993) mapped it as continuous montane coniferous forests with no subalpine coniferous forest. Most mountain ranges in the Southwest that support red squirrels have some subalpine coniferous forests. However, there are exceptions, including the relatively isolated Manazano and Pinos Altos mountains (Torrance and Grant counties, respectively) and various high-elevation points on the Mogollon Plateau, such as the San Francisco Mountains and Canovas Rim in New Mexico and the Mogollon Rim in Arizona (Brown and Lowe 1980, DickPeddie 1993). Thus, the absence of subalpine coniferous forest in the Zuni Mountains does not preclude the presence of red squirrels. Mixed coniferous forest is present in the Zuni Mountains, although it is restricted to high peaks and protected ridges and canyons. These forests even include Engelmann spruce and subalpine fir at the highest elevations (Robinson 1994). The most extensive areas of mixed coniferous forest are on Mount Sedgwick and along the northeast-facing slopes of Oso Ridge, which is the nearest high elevation in relation to El Morro (ca. $15 \mathrm{~km}$ to the northeast). Localities of specimens during early biological surveys typically were reported as the town or prominent landmark from which collecting trips originated, rather than indicating the precise collection site (Frey and Malaney 2006). Thus, it is plausible that Henshaw's specimen was collected in the Zuni Mountains (probably along Oso Ridge) but was labeled as El Morro, which was the nearest place name. This interpretation is supported by other species collected by Henshaw from El Morro during 1873 and preserved in the USNM, including the Rufous Hummingbird (Selasphorus rufus), 
Calliope Hummingbird (Stellula calliope), Western Wood-Pewee (Contopus sordidulus), Pacificslope Flycatcher (Empidonax difficilis hellmayri), Buff-breasted Flycatcher (Empidonax fulvifrons), and Pygmy Nuthatch (Sitta pygmaea). In New Mexico, each of these species is primarily, or exclusively, associated with coniferous forests (Bailey 1928).

It remains a possibility that Henshaw's record was an error (D.A. McCallum personal communication). McCallum suggested that the field number was 769 (rather than 76a), which would have fallen within a series of field numbers taken in mid-September 1873 on the Gila River in Arizona. However, because this part of the Gila River does not have suitable habitat for red squirrels, McCallum speculated that prior to reaching the Gila River, Henshaw collected the specimen in the White Mountains, Arizona, where red squirrels are known to occur (Hoffmeister 1986). While this idea has merit in that the temporal sequence of the route is essentially correct (see Webb and Axtell 1986), other facts discredit it. First, although Henshaw's field numbers generally increased temporally, this was not always the case, and many specimens did not have field numbers. Second, the month associated with the specimen is consistent with the time Henshaw collected other specimens in the vicinity of El Morro. Lastly, the trip between Camp Apache and the Gila River was ca. $96 \mathrm{~km}$, and took at least 3 days of travel (Webb and Axtell 1986). The highest elevation en route was ca. $1920 \mathrm{~m}$, but the lowest elevation record of red squirrels recorded by Hoffmeister (1986) in Arizona was $2164 \mathrm{~m}$. Thus, it is unlikely that red squirrels were collected en route to the Gila River from Camp Apache. The closest habitat of red squirrels is ca. $16 \mathrm{~km}$ east of Fort Apache on the lower slopes of Mount Baldy, which is the main massif of the White Mountains. Thus, Henshaw would have had to collect the squirrel prior to departing for the Gila River, and the specimen would have remained unprepared for $\geq 4$ days.

I conclude that the preponderance of evidence supports the historical occurrence of red squirrels in the Zuni Mountains. At present, however, red squirrels are seemingly absent from the Zuni Mountains. Despite numerous field trips to the Zuni Mountains during the 1990s and 2000s, neither I nor other biologists have observed sign of red squirrels. My inves- tigations included numerous days searching for red squirrels and their distinctive middens within mixed coniferous forests on both Oso Ridge and Mount Sedgwick. Thus, failure to find red squirrels in the Zuni Mountains likely is due to recent extirpation rather than an overlooked rare population (see Minckley 1968 for an example of a false case of presumed extirpation). Extirpation of the population on the Zuni Mountains may have been due to the small area of mixed coniferous forest in conjunction with intensive railroad logging that occurred in this mountain range during the late 19th and early 20th centuries (Glover and Hereford 1986). Recent extirpation of red squirrels in the Zuni Mountains is supported by the apparent extirpation of 2 other vertebrates from these mountains, the long-tailed vole (Microtus longicaudus) and the Blue Grouse (Dendragapus obscurus), both of which share similar distribution patterns and habitat associations in the American Southwest (Bailey 1928, J.K. Frey unpublished data).

For information about specimens and other records in their respective museums, I thank R. Fisher, S. Peurach, and C. Ludwig from USNM; L. Barbian from the National Museum of Health and Medicine; P. Jenkins from the London Natural History Museum; D. Wallace from the National Archives and Records Administration; R. Jennings from Western New Mexico University; and D. Hafner from the New Mexico Museum of Natural History and Science. This research could not have been completed without the extensive research on the Henshaw specimen completed by R. Fisher. F. Bermudez, R. Flores, J. Fraga, S. Graham, L. Lucero, L. Ponce, and S. Rios of the Student Internship Program, Wildlife Rescue Inc. of New Mexico, provided assistance in the field. I am grateful to D. McCallum for information on the Zuni Mountains and El Morro, and to J. Hubbard for information on observations of red squirrels. I thank T. Frey and K.N. Geluso for reviewing the manuscript. I thank the New Mexico Department of Game and Fish for scientific collection permits that have allowed this study and for other permits concerning the mammalian fauna of New Mexico. Partial financial support for this research was provided by the Gila National Forest and a grant from the United States Geological Survey 1448-0009-93-978. 


\section{Literature Cited}

Bailey, F.W. 1928. Birds of New Mexico. New Mexico Department of Game and Fish, Santa Fe. 807 pp.

Bailey, V. 1931 (=1932). Mammals of New Mexico. North American Fauna 53:1-412.

Brown, D.E., AND C.H. Lowe. 1980. Biotic communities of the Southwest [map]. General Technical Report RM-78, Rocky Mountain Forest and Range Experiment Station, USDA Forest Service.

Coues, E., AND H.C. YarRow. 1875. Report upon the collection of mammals made in portions of Nevada, Utah, California, Colorado, New Mexico, and Arizona during the years 1871, 1872, 1873, and 1874. Pages 35-129 in G.M. Wheeler, editor, Report upon geographical and geological explorations and surveys west of the one hundredth meridian, Washington DC.

Dick-Peddie, W.A. 1993. New Mexico vegetation, past, present, and future. University of New Mexico Press, Albuquerque. 244 pp.

FINDLEY, J.S. 1961. Geographic variation in New Mexican chickarees. Journal of Mammalogy 42:313-322.

Findley, J.S., A.H. Harris, D.E. Wilson, and C. Jones. 1975. Mammals of New Mexico. University of New Mexico Press, Albuquerque. 360 pp.

FrEY, J.K. 2004. Taxonomy and distribution of the mammals of New Mexico: an annotated checklist. Occasional Papers, Museum of Texas Tech University 240:1-31.

Frey, J.K., M.T. Hill, B.L. Christman, J.C. Truett, and S.O. MacDonald. 2008. Distribution and habitat of the Arizona gray squirrel (Sciurus arizonensis) in New Mexico. Southwestern Naturalist 53:248-255.
Frey, J.K., and J.L. Malaney. 2006. Snowshoe hare (Lepus americanus) and mountain cottontail (Sylvilagus nuttallii) biogeography at their southern range limit. Journal of Mammalogy 87:1175-1182.

Glover, V.J., AND J.P. Hereford, Jr. 1986. Zuni Mountain Railroads Cibola National Forest, New Mexico. Cultural Resources Management Report No. 6. United States Department of Agriculture and National Forest Service, Washington DC.

HaLL, E.R. 1981. Mammals of North America. John Wiley \& Sons, Inc., New York. 1181 pp.

Hoffmeister, D.F. 1986. Mammals of Arizona. University of Arizona Press and Arizona Game and Fish Department. 602 pp.

Julyan, R. 1998. The place names of New Mexico. University of New Mexico Press, Albuquerque. 385 pp.

MinckLey, W.L. 1968. Possible extirpation of the spruce squirrel from the Pinaleno (Graham) Mountains, south-central Arizona. Journal of the Arizona Academy of Science 5:110.

Robinson, S. 1994. El Malpais, Mt. Taylor, and the Zuni Mountains; a hiking guide and history. University of New Mexico Press, Albuquerque. 276 pp.

WebB, R.G., AND R.W. AXTELL. 1986. Type and type-locality of Sceloporus jarrovi Cope, with travel-routes of Henry W. Henshaw in Arizona in 1873 and 1874. Journal of Herpetology 20:32-41.

Received 14 December 2007 Accepted 9 June 2008

ApPENDIX. New records of Tamiasciurus hudsonicus in western New Mexico based on museum specimens $(n=28)$. Specimens are housed in the Museum of Southwestern Biology, University of New Mexico (MSB) and the Gila Center for Natural History, Western New Mexico University (WNMU). Catalog numbers are in parentheses. Bold numbers in brackets refer to Fig. 1.

Catron Co.: [3] Mangas Mountain, Chavez Canyon, near Upper Cat tank, T3S, R14W, S 1/2 Sec. 10, elevation $2700 \mathrm{~m}$ (MSB 75356- 75359); [4] $1.2 \mathrm{mi}$ W junction Jenkins Creek and Forest Rd. 385 on Forest Rd. 385, T4S, R21W, NW $1 / 4$ of NE $1 / 4$ of NE $1 / 4$ Sec. 15 , elevation $8620 \mathrm{ft}$ (MSB 75366); Canovas Rim, 2 mi N Forest Rd. 385 on Forest Rd. 3050, $4.5 \mathrm{mi} \mathrm{W}, 11.5 \mathrm{mi} \mathrm{N}$ Luna, T4S, R21W, NE 1/4 Sec. 4, elevation $8850 \mathrm{ft}$ (MSB 75367); Canovas Rim, $12.3 \mathrm{mi} \mathrm{N}, 3.5 \mathrm{mi} \mathrm{W}$ Luna, T3S, R21W, SE $1 / 4$ of NE 1/4 of SE 1/4 Sec. 34, elevation $9020 \mathrm{ft}$ (MSB 7536875371); Jenkins Creek, junction with Forest Rd. 385, 9.5 mi N, $2.5 \mathrm{mi} \mathrm{W}$ Luna, T4S, R21W, NE 1/4 Sec. 14, elevation $8630 \mathrm{ft}$ (MSB 75372); [5] west base Turner Peak, 5.0 mi N, $4.5 \mathrm{mi} \mathrm{W}$ Luna, T5S, R21W, NW 1/4 of NE 1/4 of NE 1/4 Sec. 9, elevation $8420 \mathrm{ft}$ (MSB 75373); [6] Tularosa Mountains, Eagle Peak, $4 \mathrm{~km} \mathrm{S,} 16.5 \mathrm{~km}$ E Reserve, T7S, R7W, NW $1 / 4$ of SE $1 / 4$ Sec. 22 , elevation $2800 \mathrm{~m}$ (MSB 75360-75365); [7] Elk Mountains, SW base Elk Mountain, T9S, R16W, NE 1/4 Sec. 2, elevation $8400 \mathrm{ft}$ (MSB 7535175352); [8] Bearwallow Mountain peak, T10S, R18W, SW 1/4 Sec. 11, elevation $3030 \mathrm{~m}$ (MSB 75353-75355). Grant Co.: [11] Aspen Grove, $9.5 \mathrm{mi}$ NE Pinos Altos, T16S, R13W Sec. 11, elevation $7600 \mathrm{ft}$ (WNMU 3972-3974); Signal Peak, $15 \mathrm{mi}$ NE Silver City (WNMU 1543); $5 \mathrm{mi}$ NE Pinos Altos, north side Signal Peak (WNMU 139). 